\title{
RANCANG BANGUN ALAT PEMBUATAN AQUA PURIFICATA (PERBANDINGAN KUALITAS PRODUK DARI REVERSE OSMOSIS, ION EXCHANGER, DAN WATER DISTILLER)
}

\author{
Robert Junaidi ${ }^{1, *}$, Yuniar ${ }^{1}$,Virwindica Bella $\mathbf{H}^{\mathbf{1}}$, Adhe Julian $\mathbf{P}^{\mathbf{1}}$, \\ Amalia Rahmah ${ }^{1}$ \\ ${ }^{1}$ Program Studi Teknologi Kimia Industri, Jurusan Teknik Kimia, Politeknik Negeri Sriwijaya \\ Jalan Srijaya Negara, Bukit Besar, Palembang 30139, Telp. (0711) 353414 / Fax. (0711) 355918 \\ "E-mail: roju@ polsri.ac.id
}

\begin{abstract}
ABSTRAK
Penelitian dilakukan untuk merancang proses produksi aqua purificata dan memurnikan air keran dengan memasang dan menggabungkan penyaringan multi-tahap dengan metode lain seperti, reverse osmosis, pertukaran ion, dan unit distilasi. Tujuan penelitian ini adalah untuk membandingkan kualitas produk dari setiap outlet unit akhir sehingga dapat ditentukan mana yang memenuhi spesifikasi standar. Proses pemurnian air umpan dalam reverse osmosis dilakukan dengan memvariasikan tekanan operasional dalam 20, 40, 50, dan 60 bar. Pada penukar ion, pengamatan dilakukan dengan menentukan pengaruh laju aliran umpan terhadap keluaran dengan variasi 100,125, dan $150 \mathrm{ml} /$ menit. Selain itu, dalam penyuling air, proses pemanasan di dalam unit dipengaruhi oleh laju aliran umpan $0,2055 \mathrm{~L} / \mathrm{mnt}$ dan volume output dikontrol oleh waktu operasi dengan kisaran 5, 10, 15, 20, dan 25 menit. Menurut nomor spesifikasi ASTM D1193-91 dan NCCLS dari hasil pengukuran, aqua purificata yang dihasilkan oleh reverse osmosis dan penyuling air dikategorikan sebagai tipe 1 .
\end{abstract}

Kata kunci: Aqua purificata, air ledeng, penukar ion, penyuling air, reverse osmosis

\begin{abstract}
The research done to design a production process of aqua purificata and purify the tap water by installing and combining the multi-stage filtration with other methods, such as reverse osmosis, ion exchange, and distillation unit. The goal is to compare the product quality from each outlet of final units and determine which one is fulfilled the standardized specification. Purification process of feed water in reverse osmosis is done by varying the operational pressure within 20 , 40, 50, and 60 bar. In ion exchanger, the observation is done by determining the effect of feed flow rate to output with variation of 100,125 , and $150 \mathrm{ml} / \mathrm{min}$. Besides, in water distiller, the heating process inner the unit is affected by feed flow rate of $0.2055 \mathrm{~L} / \mathrm{min}$ and the output's volume is controlled by the operating time with 5 minutes-range of $5,10,15,20$, and 25 minutes. According to the specification number of ASTM D1193-91 and NCCLS from the measurement result, the aqua purificata that is produced by reverse osmosis and water distiller are categorized as type 1 .
\end{abstract}

Keywords: Aqua purificata, ion exchanger, reverse osmosis, tap water, water distiller.

\section{PENDAHULUAN}

Aqua purificata merupakan air bersih yang mengalami proses pemurnian sehingga terbebas dari kandungan mineral dan baik digunakan untuk keperluan di sektor akademis maupun non akademis seperti industri, medis, dan farmasi (Hasanah, 2016). Kebutuhan aqua purificata di Kota Palembang terbilang besar.Hal itu disebabkan oleh banyaknya kegunaan aqua purificata dalam praktiknya seperti pelarut bahan kimia, 
pembuat reagen, pembersih glass ware, dan lain-lain. Akan tetapi, kebutuhan akan bahan pelarut utama itu tidak didukung dengan pengadaan yang sama oleh penyedia. Inilah yang mendorong peneliti untuk melakukan penelitian pembuatan aqua purificata dengan mengolah air kran menggunakan kombinasi proses filtrasi bertahap dengan metode pemanasan dan tanpa pemanasan seperti reverse osmosis, pertukaran ion, juga penguapan atau distilasi. Air umpan yang digunakan berasal dari air yang didistribusikan oleh perusahaan air milik pemerintah daerah.

Proses pengolahan yang bersifat gradual dari air bersih menjadi aqua purificata ini diharapkan agar air yang dihasilkan dapat memenuhi spesifikasi yang mengacu pada standar yang digunakan yaitu American Society Testing Method(ASTM) D1193-91 dan National Chemical Clinic Laboratory Standard(NCCLS). Spesifikasi tersebut antara lain berupa konduktivitas (daya hantar listrik), Total Dissolved Solid(TDS), derajat keasaman ( $\mathrm{pH})$, dan resistivitas (hambatan listrik pada bahan).

Guna meringankan kinerja masing-masing unit yang memiliki output berupa aqua purificata, maka proses purifikasi air diiniasi dengan cara dilewatkan melalui alat penyaring. Alat penyaring yang digunakan berupa membran yang dibedakan berdasarkan ukuran porinya yaitu mikrofilter dan ultrafilter dan berjumlah 3 buah yakni mikrofilter berukuran pori 0,3 dan $0,1 \mu \mathrm{m}$ serta ultrafilter $0,01 \mu \mathrm{m}$. Mikrofiltrasi (MF) merupakan membran mikroporus dengan ukuran pori efektif berkisar antara 0,07-13 $\mu \mathrm{m}$ untuk menyaring kontaminan seperti partikel berukuran $0,1-0,2 \mu \mathrm{m}$, material padatan, dan mikroba (Wenten, 1999).

Sementara itu, ultrafiltrasi (UF) adalah proses pemisahan bermembran dengan ukuran pori berkisar antara $0,1-0,001 \mu \mathrm{m}$ yang berfungsi untuk menghilangkan kontaminan berupa zat berberat molekul tinggi, partikel koloid, serta material organik atau anorganik (Said, 2009). Partikel terlarut dalam air yang sudah dihilangkan melalui proses pemisahan dengan membran tersebut belum membuat spesifikasinya mendekati standar. Air dengan tingkat kemurnian tinggi akan dihasilkan dari keluaran unit seperti reverse osmosis, ion exchanger, dan water distiller.

Reverse osmosis (RO) atau osmosis balik adalah proses pemisahan tanpa melibatkan energi termal tetapi menggunakan tekanan yang tinggi melewati membran dengan kerapatan nano. Air yang lolos melewati membran disebut permeat, sedangkan yang tertolak atau tidak mampu melewati membran disebut konsentrat. Pemurnian air yang memanfaatkan reverse osmosis ini bergantung pada sejumlah faktor seperti ukuran membran, ukuran pori membran, suhu dan tekanan operasi, serta luas permukaan membran (Montgomery, 2005).

Karakteristik membran RO dapat diketahui melalui permeabilitas dan permselektivitas yang dimilikinya. Permeabilitas menyatakan ukuran kecepatan atau fluks suatu spesi tertentu untuk melewati membran, sedangkan permselektivitas adalah kemampuan membran untuk menahan atau melewatkan suatu spesi tertentu.

Adapun, ion exchanger atau penukar ion dengan media berupa resin didefinisikan sebagai senyawa hidrokarbon terpolarisasi yang mengandung ikatan silang (crosslinking) serta gugus-gugus fungsional yang mempunyai ion-ion yang dapat dipertukarkan (Zainudin, 2013). Ketika dikontakkan dengan ion exchanger, ion yang terlarut di dalam air akan terserap ke resin dan resin akan melepaskan ion-ion lain dalam kesetaraan ekuivalen. Dengan menentukan kondisi tersebut, 
maka dapat mengatur jenis ion yang akan diikat dan dilepas.

Resin yang digunakan terdiri atas dua jenis resin yaitu kation dan anion dengan masing-masing dua macam yaitu lemah dan kuat. Mekanisme pertukaran ion menyangkut salah satu penempatan ion yang diberikan oleh spesi dari material yang tidak dapat larut dengan ion-ion yang berbeda spesi ketika larutan yang terakhir dibawa sampai terjadi pengontakkan.Sifat-sifat penting yang diharapkan dari media penukar ion adalah daya pengambilan (kapasitas), selektivitas, kecepatan pertukaran, ketahanan terhadap suhu, dan ketahanan terhadap penukar ion yang telah diperbarui. Terdapat dua pendekatan yang berguna dalam menentukan kapasitas resin yang digunakan yaitu pendekatan volume produk/waktu dan pendekatan volume resin. Kedua proses yang telah dijelaskan sebelumnya adalah tergolong ke dalam metode tanpa pemanasan.

Aqua purificata yang dihasilkan juga dikenal sebagai aqua demin.Tak hanya itu, aqua purificata bisa pula dibuat melalui metode pemanasan yang sering disebut dengan akuades.Metode ini melibatkan energi termal yang bersumber dari listrik, surya, dan steam serta dinilai ekonomis dan dapat digunakan dalam skala besar. Metode pemanasan ini memanfaatkan proses penguapan layaknya siklus air yang terjadi di Bumi atau evaporasi (distilasi). Perbedaan kedua proses tersebut terletak pada fase yang terlibat dalam proses pemisahannya. Pada evaporasi, fase cair dipisahkan dari padatan yang terlarut di dalamnya.Sementara distilasi, pemisahan melibatkan kedua zat yang berfase sama yaitu cair-cair (Treybal, 1981).

Beberapa faktor yang dapat memengaruhi proses penguapan adalah laju alir umpan, lama waktu, suhu, tekanan operasi, daya elemen pemanasan, kapasitas unit pemanasan, laju alir keluar, dan bahan kontruksi unit pemanasan. Unit pemanasan atau water distiller berperan sebagai kolom yang memanaskan air sampai mencapai titik didihnya sehingga ruang gerak pada molekul cairan akan membesar yang membuat fase uap terlepas dari fase cair dan membentuk uap. Uap yang dihasilkan tersebut akan didinginkan kembali menggunakan kondensor.

\section{METODE}

Bahan yang digunakan dalam penelitian ini adalah air keran yang berada di Laboratorium Teknik Kimia yang merupakan campuran air yang berasal dari perusahaan pengolah air milik pemerintah daerah setempat dengan air reservoir yang terletak di belakang lab. Sebelum digunakan pada proses pemurnian, air keran perlu dilakukan analisis awal terhadap parameter fisik dan kimia seperti konduktivitas, $\mathrm{pH}$, resistivitas, dan TDS. Pemeriksaan ini bertujuan untuk mengetahui potensi air keran yang akan dimurnikan. 


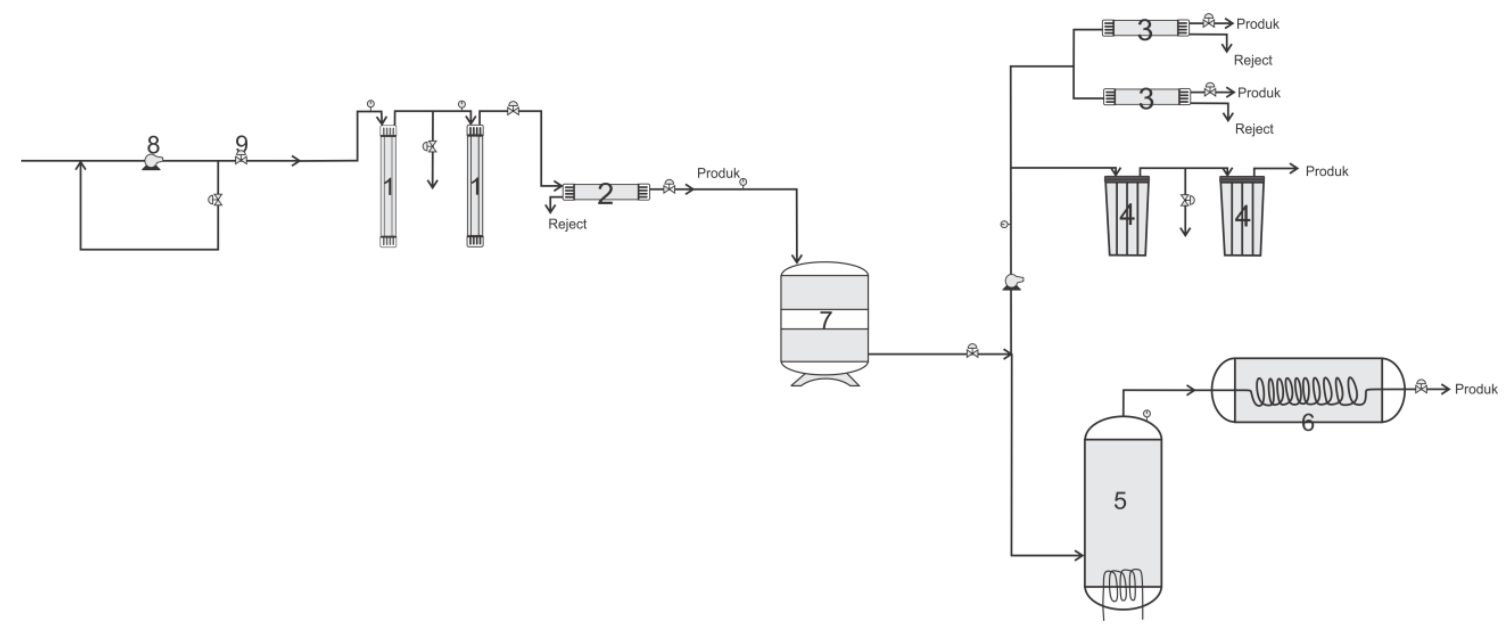

Gambar 1. Rangkaian Alat Pembuatan Aqua Purificata

1. Tangki Mikrofiltrasi $0,3-0,1 \mu \mathrm{m}$

2. Tangki Ultrafiltrasi $0,01 \mu \mathrm{m}$

3. Reverse Osmosis

4. Ion Exchanger

5. Water Distiller

Gambar 1 merupakan seperangkat pemurnian yang digunakan dalam proses pembuatan aqua purificata. Instalasi sejumlah unit menjadi satu rangkaian dinilai bersifat lebih ergonomis dibandingkan jika dipisah-pisah. Tahapan mula-mula penelitian adalah menghubungkan alat ke sambungan listrik yang akan menyalakan pompa umpan. Tangki Umpan disiapkan sebagai media penampungan sementara bahan yang digunakan selain dari air keran, misalnya air sumur.

Air yang ditarik oleh pompa akan dialirkan menuju ke kolom mikrofiltrasi $0,3 \mu \mathrm{m}$ dan $0,1 \mu \mathrm{m}$ dan dilanjutkan ke ultrafilter $0,01 \mu \mathrm{m}$. Mikrofilter dan ultrafilter yang digunakan berjenis hollow fiber. Setelah diproses dalam penyaring rangkap, air akan diakumulasikan terlebih dahulu di dalam Tangki Penampungan Sementara berkapasitas \pm 100 L lalu dilakukan pengambilan sampel awal sebelum dialirkan ke tiga peralatan pemurnian utama yaitu reverse osmosis, ion exchanger, dan water distiller. Tiap sampel diukur parameternya menggunakan alat Cyberscan Waterproof.
6. Kondensor

7. Tangki penampungan sementara

8. Pompa

9. Valve

Dengan menekan saklar pompa pada peralatan, maka air dapat diumpankan menuju reverse osmosis dan ion exchanger. Sementara itu, air yang menuju ke water distiller dapat diumpankan dengan cara membuka valve yang tersedia pada saluran outlet Tangki Penampung Sementara.

Proses pembuatan aqua purificata pada reverse osmosis dilakukan dengan memvariasikan tekanan operasional dalam 20, 40, 50, dan 60 bar. Pada ion exchangerdigunakan dua buah cartridge yang berukuran 10 inchi, tiap cartridge berisi 350 gr resin kation ataupun anion. Resin yang digunakan adalah Kationex A-4 dan Resinex K-8. Pada Ion exchanger dilakukan variasi laju alir umpan terhadap keluaran 100, 125, dan $150 \mathrm{ml} /$ menit. Selain itu, pada water distiller, proses pemanasan di dalam unit dipengaruhi oleh laju alir umpan 0,2055 L/menit dan volume output dikontrol oleh waktu operasi dengan kisaran 5 menit dengan kisaran 5, 10, 15, 20, dan 25 menit. Tiap sampel diukur parameternya menggunakan alat Cyberscan Waterproof. 


\section{HASIL DAN PEMBAHASAN}

Dalam rancang bangun alat pembuatan aqua purificata ini, peneliti mencoba untuk melakukan perbandingan parameter fisik produk yang didapatkan dari tiga proses yang berbeda tersebut dengan meninjau penurunanTDS dan konduktivitas produk yang dihasilkan oleh setiap proses terhadap umpan.

Berdasarkan ASTM D1193-91, ada empat tipe air reagen baku yang memiliki nilai yang berbeda-beda untuk setiap parameter yang diamati baik fisik maupun kimia.

Air reagen Tipe I dibuat dengan metode penyulingan atau proses yang sama yang didukung dengan penyaring membran berukuran pori mikro yang mana sebelum dialirkan ke kolom penyaringan, air umpan harus memiliki konduktivitas maksimum sebesar $20 \mu \mathrm{S} / \mathrm{cm}$ (ASTM D1193-91).

Begitu juga dengan air reagen Tipe II, III, dan IV yang disiapkan melalui proses-proses kombinasi antara distilasi dan penyaringan serta reverse osmosis dan elektrodeionisasi. Kemampuan kerja yang dimiliki oleh ketiga unit tersebut dapat dilihat dari penurunan parameter yang dieliminasi dari air umpan.Data pengukuran sampel sebelum diolah ke tiap unit ditunjukkan oleh Tabel 1.

Tabel 1. Pengukuran Parameter Sampel Sebelum Diolah di Tiap Proses

\begin{tabular}{lccc} 
Parameter & WD & RO & $I E$ \\
\hline TDS (ppm) & 8,15 & 8,15 & 8,17 \\
$\begin{array}{l}\text { Konduktivitas } \\
(\mu \mathrm{S} / \mathrm{cm})\end{array}$ & 8,15 & 8,16 & 8,16 \\
Derajat $\mathrm{pH}$ & 6,98 & 6,98 & 6,98 \\
\hline
\end{tabular}

Berikut adalah hasilperbandingan penurunan TDS produk aqua purificatadari tiga proses berbedayaitu reverse osmosis, ion exchanger, dan water distiller ditampilkan pada Gambar 2.

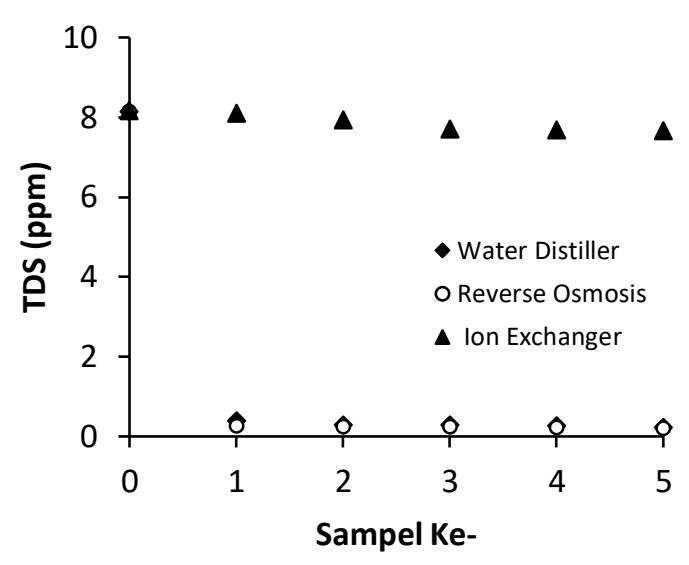

Gambar 2.Grafik PenurunanTDS pada Tiga Proses Berbeda

Gambar 2 menunjukkan hasil pengukuran TDS ditinjau dari keluaran yang diperoleh dari tiap unit berdasarkan kondisi operasi.Diketahui kemampuan dari masing-masing unit yaitu water distiller, reverse osmosis, dan ion exchanger untuk menyisihkan kandungan padatan terlarut dalam air umpan sehingga menghasilkan produk aqua purificata adalah berbeda-beda.

Aqua purificata yang dihasilkan dari water distiller dan RO masing-masingmasih memiliki TDS sebesar 0,24 dan 0,22 ppm yang menunjukkan bahwa produk aqua purificata keluran dari water distiller dan RO memenuhi syarat air bebas mineral TDS $\leq 1$ ppm (NCCLS) untuk tipe 2yang mengindikasikan bahwa kemampuan penghilangan kandungan mineral dari kedua unit ini cukup efektif.

Water distiller dioperasikan pada tekanan atmosferik menggunakan laju alir umpan sebesar 0.2055 L.min ${ }^{-1}$ menuju unit. Dengan laju alir umpan tersebut, laju kenaikan suhu di dalam water distiller berada dalam keadaan efektif untuk proses pemanasan bahan di dalam unit yaitu $0.8 \mathrm{C}^{\circ} \cdot \mathrm{min}^{-1}$. Hal itu juga ditunjukkan oleh Gambar 3 mengenai efisiensi termal water distiller yang berkisar antara 60-70\% sehingga 
penyerapan panas yang dilakukan oleh air dapat cukup untuk mengubahnya menjadi uap.(Nuryanti, 2013).

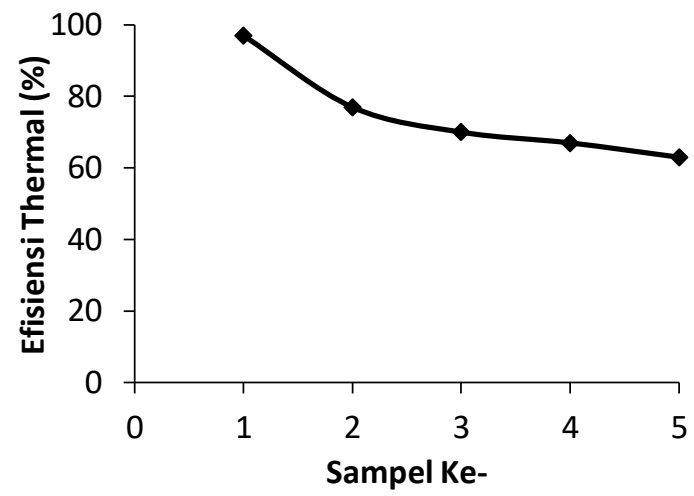

Gambar 3. Grafik Efisiensi Termal padaWater Distiller

Sementara itu, pada ion exchanger, produk yang dihasilkan masih memiliki jumlah TDS yang mendekati umpan sehingga penyisihannya masih kecil.Pada ion exchanger, penurunan TDS terendah produk aqua purificata adalah 7,67 ppm. Keluaran dari ion exchanger tidak bisa memenuhi syarat air bebas mineral karena TDS air keluaran ion exchanger harus paling tidak memiliki harga 5 ppm (NCCLS) untuk tipe 3. Hal ini dikarenakan waktu kontak resin dan umpan yang singkat $(100 \mathrm{ml} /$ menit $)$ sehingga proses pertukaran ion tidak optimal dan ion air pengotor masih terbawa keluar ion exchanger.

Jumlah TDS pada umpan yang dapat dihilangkan juga akan berdampak pada nilai konduktivitasnya. TDS yang tersisihkan mengakibatkan konduktivitas ikut menurun seperti yang ditunjukkan oleh Gambar 4.

Pada Gambar 4, dapat diketahui konduktivitas dari air umpan yang dialirkan ke dalam ketiga proses tersebut dapat diturunkan.Hampir sama dengan penurunan TDS, konduktivitas air umpan yang diturunkan melalui proses penguapan di water distiller dan RO terjadi dalam jumlah yang lebih besar dibandingkan dengan ion exchanger.

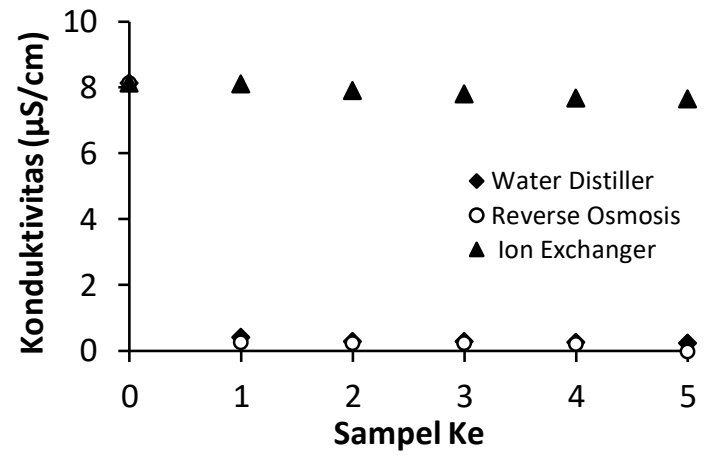

Gambar 4. Grafik Penurunan

Konduktivitas pada Tiga Proses Berbeda

Aqua purificata yang dihasilkan dari water distiller dan RO masing-masing masih memiliki konduktivitas sebesar 0,24 dan $0,21 \mu \mathrm{S} / \mathrm{cm}$ yang menunjukkan bahwa produk aqua purificata keluran dari water distiller dan RO memenuhi syarat air bebas mineral konduktivitas $\leq 4 \mu \mathrm{S} / \mathrm{cm}$ untuk tipe 3 dan $\leq 1 \mu \mathrm{S} / \mathrm{cm}$ untuk tipe 2 (ASTM D1193-91) yang mengindikasikan bahwa kemampuan penghilangan kandungan mineral dari kedua unit ini cukup efektif.

Berdasarkan Gambar

4 , Konduktivitas aqua purificata keluaran ion exchanger harus paling tidak memiliki harga $5 \mu \mathrm{S} / \mathrm{cm}$ (ASTM D1193-91). Konduktivitas terendah yang didapatkan adalah 7,68 $\mathrm{mS} / \mathrm{cm}$ pada laju $100 \mathrm{ml} / \mathrm{menit}$. Hal ini menunjukan indikasi tidak keberhasilan resin dalam menukar ion, yang artinya air memiliki daya hantar listrik yang tinggi dan tidak memenuhi syarat (Mustaqihul, 2009). Hal ini disebabkan belum terpenuhinya waktu kontak antara resin dengan air sehingga reaksi pertukaran ion antara kation dan anion dari air dengan kation dan anion resin penukar ion belum terjadi.

Dengan demikian, Sistem ion exchanger memerlukan perlakuan evaluatif sehingga dapat menghasilkan aqua purificata dengan parameter TDS dan konduktivitas yang mendekati 
standar NCCLS maupun ASTM D1193-91.

\section{SIMPULAN}

Berdasarkan hasil pengamatan pada alat pembuatan aqua purificata menggunakan tiga proses yang berbeda, maka dapat ditarik beberapa kesimpulan sebagai berikut:

1. Produk water distiller dan RO termasuk ke dalam klasifikasi air reagen Tipe II pada standar NCCLS (total solids $\leq 1 \mathrm{ppm}$ ) dan ASTM D1193-91 (Konduktivitas $\leq 1 \mu \mathrm{S} / \mathrm{cm}$ ) yang memiliki jumlah TDS terendah masing-masing sebesar 0,24 dan 0,22 ppm serta konduktivitas 0,24 dan $0,21 \mu \mathrm{S} / \mathrm{cm}$.

2. Produk dari ion exchanger memiliki TDS 7,67 ppm dan koduktivitas 7,68 $\mu \mathrm{S} / \mathrm{cm}$ tidak dapat disebut sebagai aqua purificataatau air bebas mineral dikarenakan tidak memenuhi standar NCCLS maupun ASTM D1193-91.

3. Kemampuan penurunan jumlah TDS dan konduktivitas di dalam air umpan pada Water Distiller dan RO lebih besar daripada ion exchanger.

\section{DAFTAR RUJUKAN}

ASTM D1193-91. 2003. Standard Specification for Reagent Water. United States: Association of Standard Testing Materials.

Hasanah, Faridatul. 2016. Desain Sensor Kapasitif Untuk Penentuan Level
Aquades.Jurusan Fisika FMIPA: Universitas Jember.

Montgomery, J.M. 2005.Water Treatment Principles and Design. USA: Johan Weley Inc.

Mustaqihul. 2009. Pembuatan Aquadm (Aquademineralized) dari Air AC (Air Conditioner) Menggunakan Resin Kation dan Anion. Semarang: Jurusan Kimia Universitas Diponegoro.

Nuryanti, Athin. 2013. Pemisahan fraksi sitronellol dan geraniol minyak sereh wangi menggunakan distilasi molekuler. Jurusan Teknologi Industri Pertanian: Institut Pertanian Bogor.

National Committee for Clinical Laboratory Standards (NCCLS). 1988. Water Quality Standard.

Said, Nusa Idaman. 2009. Uji Kinerja Air Siap Minum dengan Proses Biofiltrasi, Ultrafiltrasi dan Reverse Osmosis (RO) dengan Air Baku Air Sungai. Jurnal air Indonesia, Vol (5), 2.

Treybal, Robert. 1981. Mass Transer Operations. USA: McGraw Hill Companies.

Wenten, I.G. 1999. Teknologi Membran Industrial. Bandung: Institut Teknologi Bandung.

Zainudin.2013. Pembuatan Resin Penukar Ion Polistiren Sulfonat. Departemen Kimia Fakultas MIPA, Universitas Padjajaran 